\title{
Special Aspects of Arabic Teaching in Tatar Schools and Madrasas at the End of the XIX - Beginning of the XX Centuries
}

\author{
Aida Fattakhova \\ Kazan (Volga Region) Federal University, Institute of International Relations, History and Oriental Studies, Russian Federation \\ Email: gaidaf@mail.ru
}

Doi:10.5901/mjss.2015.v6n3s1p131

Abstract

The article deals with special aspects of Arabic Teaching in Tatar schools and madrasas at the end of XIX - beginning of XX centuries in the light of Arabic textbooks preserved up modern times. The author investigates continuity of Arabic Linguistic traditions in writing and publishing books on Arabic Grammar for Tatars. Tatar teachers of Arabic tried to find their own approach to an educational process which allows to preserve and show the feature of a foreign language to implement practical and theoretical objectives. Taking into account today's public attention to Arabic in educational fields the address to experience is very important because it gives an opportunity to avoid mistakes and to develop the methods of Arabic teaching for Tatars used by teachers of Arabic at the end of XIX - the beginning of XX centuries.

Keywords: Arabic textbook, Arabic translation, alphabetic method, syllabic method

\section{Introduction}

The history of Arabic learning by Tatars roots in far past. It is connected with Islam adoption by the Tatar ancestors in the Volga Bulgaria and the alphabet foundation on the basis of Arabic script. As the source of religious doctrine is the Koran, the need for proper reading and understanding the exact meaning of the text, as well as the understanding of hadiths and religious books stimulated Tatars to learn the Arabic language.

According to Orthodox missionary J. Koblov (1876 -?), the need of Tatars to study Arabic is attributed to the fact that they will speak Arabic in Heavens and they will be interrogated beyond the grave also in Arabic: "Before entering the paradise on the day of resurrection, they say, the believers will be interrogated in Arabic "(1916, p. 18).

Factual materials on learning the Arabic language in Tatar secular and religious schools with a description of the history of Arabic teaching and review of academic literature of the Arab-Muslim authors can be found in works of $\mathrm{J}$. Validov (1923) and Y. Koblov (1916).

At his time, the educator N. Katanov conducted a research on Arabic textbooks $(1897,1898,1901)$.

In the journal "Doer", he presented some information in the chapter "Eastern Bibliography" about some textbooks published in Kazan with an indication of the output data and a brief description of the content.

In his book "Description of Arabic manuscripts belonging to the library of the Imperial Kazan University", Gottwald (1855) presented some information about the Arabic textbooks written by Arab-Muslim writers of the Middle Ages.

A detailed description of Arabic textbooks written for Tatars, including grammatical treatises, is given in the work of R. Safiullina (2003) where the history of Arabic-language books written specially for Tatars is represented.

In his research, Salakhov (2010) investigated the Arab treatises written by medieval oriental authors and several books on Arabic grammar written in Tatar.

In order to reveal how Arabic teaching has been affected by Arabic literature textbooks, this paper investigates the features of Arabic teaching for Tatars in secular and religious schools of pre-revolutionary period of the late XIX - early $X X$ centuries through the educational literature of Arabic preserved nowadays.

This is because the earlier period, namely the problems of Arabic teaching - programs, textbooks and instructional techniques used in the days of the Volga Bulgaria, Golden Horde and the Kazan Khanate had vanished.

\section{Main Body}

Consequently, the authors used the descriptive method, which gave them the opportunity to investigate the academic literature of Arabic written for Tatars and had been used in Tatar secular and religious schools till 1917. They also used 
the comparative-historical method to analyze the textbooks of Arabic that refer to different periods of time.

The materials for the study were Arabic textbooks of Arabian and Tatar authors. We have analyzed ten traditional treatises of Arab-Muslim authors of the past (Al-Zamakhshari "Al- Anmūdhaj" (1885), Abd al-Qahir Al-Jurjani "Al-'Awāmil al-mi'a", Ibn al-Hajib "Al-Kāfiya" (1891) and other), about fifty textbooks of Arabic written by Tatar authors (S. Bikbulatov (1913), G. Bubi (1899), A. Maksudi (1904, 1912), R. Fakhretdinov (1887) and other), and a few Tatar Grammar textbooks copied from Arabian grammatical compositions (Kh. Galikaev (1899), G. Baroudi (189-) and other).

2.1. Educational institutions of Tatars consisted of two levels: 'mekteb', a religious primary school where children learned

Arabic and fundamentals of religion necessary for all Muslims and 'madrasa', consisting of a secondary school and a higher educational institute which educated the staff for teaching Arabic and religion fundamentals.

Pre-revolutionary educational institutions had two separate types of schools - the schools that used an old methodology and the schools that used a new one. Besides, the schools, where teachers used old methodology while teaching Arabic, had an objective to teach reading the Koran and religious books that were written in Arabic. Primary education students, on the other hand, joined mektebs where the course programs were not designed. Instead, the teachers used religious books containing dogmas and the stories of prophets' biographies.

The educational process in mektebs depended on the skills of mullahs and khalfs (note 1) whose education was based on methodology of scholastics. Instead of textbooks, they used certain religious books. Usually they started to teach Arabic with the book "Sharā'it al-imān" (Conditions of the Faith) - Tatars named it "Iman Sharty" or "Alyabbi", "Aliphbi, "Alpi" (ABC book) - the name of the first two letters of old Tatar alphabet based on Arabic script (Ibragimov, 1969, p. 89).

The author's name of the Abs book is still unknown. Contents of the alphabet book "Iman Chartier" includes the alphabet, letters with diacritical marks, shapes of the letters (initial, middle and final) and abjad (note 2). Abjad consisting of eight fictional Arabic words instead of lexical meaning had a numeric one and indicated the ancient order of the Arabic alphabet, borrowed from the Jews.

For learning abjad, pupils spent from one to two weeks. Then they began to study religious texts. Thus, the pupils, who did not yet learn the letters, started to read the Arabic phrases the meaning of words which they were not able to understand (Validov, 1923).

Proceeding from the content, it is easy to imagine how difficult it was to learn using such the $A B C$ book for students, as the ABC book did not contain any texts, exercises and assignments appropriate to the level of children's development, exercises and assignments, and most importantly, there were no any pictures, which are so important in teaching children at the starting level.

Next the ABC book offered religious texts - prayers, explanations of 40 duties for a Muslim in Tatar and brief creed in verse. Alphabet book "Iman Sharty" was used as the only textbook in all mektebs of Kazan province and students studied it during the first year of school. The teaching process of Arabic reading was based on the alphabetic method, the essence of which was reduced to the mechanical mangling of letters in alphabetical order and the names of subscript and superscript characters (Harakat) denoting vowels.

To denote Harakats, Tatars used their own signs, which were defined by a graphic image and the position of Harakats in the word. For example, a short sound "a", Fat-ha, designated öst (above, from the top), "i" kasra - ast (from below), "u" Dhamma - ütür (looks like a comma but it is put at the top of the letter to show haraka of the sound).

At one time, editions started to criticize the alphabetic method due to the fact that students mechanically memoriz the syllables and words without understanding the process of their formation. For example, in the journal "Shura" of 1911 H., Ramiev wrote in his article "Methods of teaching language and literature": "Speaking of the alphabetic method, I am giving the example of the word 'kalimatun', the meaning of which was explained in the following way: "Kaf Fat-ha means 'ka', lam kasra means 'li' (kali), then, mim Fat-ha means 'ma' and if you add to "ta" two Dhammas, you get "tun", i.e. 'kalimatun' (p. 54).

Then the author writes that if the teachers were Halfs and Abystais, the process of the word explanation turned to be much more complicated. We are giving the example of the expression without translation because only the original language can display phonetic nuances of its study: "kabsin -ka, kali misma- kalimə, tigiiketyrtyn - kalimatun." The author asks indignantly: "How can we get 'ka' from 'kapsin' ?" (p. 54).

In the opinion of the eminent missionary Malov, such a situation has arisen because the Tatars shortened the names of some short vowels. So, instead of 'öst' or 'östen' and 'östendä' they pronounced 'sin', for example: alif sin - a, bi $\sin -b a$, etc. Similarly, instead of astin they speak only asin: bi asin - bi. Finally, instead of ütür they say tür: bi tür - bu (1894, p. 14-15). Such a change of names, as Malov wrote, happened not once, but gradually, due to frequent mechanical pronunciation of syllables by teachers and students. It is obvious now how difficult was it for children to 
master the alphabetic method of reading. Nevertheless, namely this method became the basis for getting primary education for both Tatar and Russian students.

After mastering the Arabic alphabet with all kinds of syllables, students started to read the books. In some communities, students who learned the alphabet were called "tahtahanas" (students reading the board) because that time all the letters in multiple type a teacher wrote on a wooden board in order a student to memorize them. After starting to read, the students got the names of "kitabhanoms", i.e., students reading a book (Koblov, 1916).

After the alphabet, children began reading religious texts in the following order: "Yasin" - 36th sura of the Koran published as a separate book then they started reading "Heftiek" - one-seventh of the Koran, which was also published as a separate book.

The third and fourth years of study in mektebs were targeted on reading and memorizing the Koran. How effective was the training of the Koran, the Tajik writer, philosopher and educator Donish Ahmad (1827-1897) clearly described in his book "Journey from St. Petersburg to Bukhara" (1960): "In memorizing the Koran, I was negligent: hardly mastering one part I started the other one. Sometimes, not having learned the lesson by laziness, I wrote it on a piece of paper and secretly read by cribs. Any way the teachers failed to uncover stubbornness from my heart and only in the three years I mastered the Koran with great difficulty and soon I faced the same difficulties but with greater extent. I got sick and tired of it and got lazy and grew dull. I lost all my abilities and my memory got weakened completely" (p. 212-213). So, the primary education program was complicated and one-sided. Nevertheless, it should be noted that among the peoples of the eastern part of Russia at that time the literacy rate of the Tatars was the highest.

For teaching Arabic, in madrasas using old methodology, teachers - instead of textbooks - used manuscripts that were usually copied by the students themselves and the books brought from Egypt, Turkey and Central Asia. After invention of printing, the print edition superseded the hand-written books and ensured the preservation of grammatical treatises that were previously written in the manuscripts from extinction. After the spread of printing, the method of copying books did not disappear but it served exclusively as the training exercise for writing teaching (Validov, 1923).

Learning Arabic in madrasas Tatar madrasas started with the study of morphology - an anonymous treatise written in Persian - "Muqaddima Bidān ma'a sharḥ 'Abdallaḥ" (Introduction into Bedan with Abdullah's explanations) widely known - in Central Asia and the Volga region - in his initial words "bedan", which in Persian means "you must know". This book was compiled for Persian-speaking children, and it was brought from Bukhara by Tatar teachers who had got their education there. (Validov, 1923). Thus, the young students starting to learn the grammar in the age of 10-15 learned foreign language (Arabic) by the means of another foreign language (Persian). Students in madrasas were divided into stages the names of which were defined by the name of the book they studied during a certain period of training. So students, learning the book "bedan" were called "sarf-Khan" (the one reading morphology) or "Sharh-Abdullakhan" (reading the explanation of Abdullah) and they were the students of the first stage.

Preserved documents show that the Tatar schools possessed valuable works on grammar that played an important role in the field of Arab linguistics during the medieval period. These writings, compiled in the late period of the history of classical Arab philological tradition, presented the Tatar folk of the Arab linguistic tradition: "Al-Kāfiya" (enough) written by the Egyptian scholar Ibn al-Hadzhibey (1175-1249) (1891), "Al- Anmūdhaj "(Sample) written by eminent Khorezm's scholar and philologist Mạ̣mud B., 'Umar al-Zamakhshari (1074-1144) (1885), "Al-'Awāmil al-mi'a" (One hundred factors of management written by a representative of Baghdad school,' Abd al-Qahira al-Jurjani (died in 1078) (al-Jurjani) and others.

Books of the Arab-Muslim authors were incomprehensible for students, who eventually had to just memorize the training material without understanding. For teachers, those books were also of considerable complexity since their task was to explain the material in clear and accessible way. It was not easy to achieve this goal because some textbooks of Arabic were written in Persian. How unpleasant was the fact that these writings - the pearls of Arab linguistics used by the teachers of traditional school hindered the mastering of Arabic and, as it was told, sometimes caused rejection of its learning. Not knowing the basic rules of the language and not knowing a sufficient number of words, students had to learn the interpretation of the grammarians and their comments. Certainly these writings were not designed for Tatar-speaking audience and they did not match the level of the students and their capabilities.

We cannot say that after completing the course in morphology and syntax the students knew well grammatical theory, skillfully used the terminology and could properly make sentences and phrases in Arabic. "Students were not seriously interested in grammar itself. Moreover, this discipline, according to the educational program of madrassas, was designed for the first three stages of learning, i.e., for the boys of 10-15 years old who were too small to show a more serious attitude toward science "(Validov, 1923, p.26). At that time, grammar was considered as a necessary step to learn religion followed by endless discussions. However, it should be noted that Tatar school did not have more understandable books of Arabic before 1887. Thus, having a good selection of books, methods of teaching of Arabic 
were far from being perfect.

2.2.At the turn of the XIX-XX centuries, the specific orientation of students who completed the course in madrasas, "who learned hard to keep the exams but were suitable for being mullahs or selling themselves for 15 rubles a month working in mektebs as teachers" (Bobrovnikov, 1913, p. 53), did not correspond the realities of the developing capitalist society. Schools that used new methodology and replaced schools used old methodology. Along with learning to read the Koran and the formation of spiritual and moral values of a personality, they also focused also on the practical training of the younger generation and included a large number of secular subjects in the curriculum. Progressive-minded educators, community and religious leaders designed new training programs, plans and textbooks for Arabic learning. They developed new training methods that were directed to improve the educational process whereas the number of secular classes was increased. Arabic, despite a large number of secular subjects, including the Russian language, continued to take a leading position in the educational process of schools and madrassas of a new type.

In the publication "The program of six-year primary school", we can read the following: "If one of the main goals of the school is learning Russian, the second one is teaching religion. On these grounds, we are unable to get rid of the Arabic and cannot reduce a number of classes for its learning"(1916, p. 6).

New reformed schools were equipped with blackboards, desks, teaching aids, maps and the appropriate conditions of hygiene. Students in madrassas accepted boys if they have a passport, certificate of primary education and a certificate of health. To be admitted to madrasa the boys had to show the passport, the primary school certificate and the heath certificate.

In schools using new methodologies, the alphabetic method of teaching was replaced by the syllabic one. Using the syllabic method, teachers showed students vowels then subsequently joined them to consonants. Depending on how many vowels the Arabic alphabet has, so many times students had to join them to consonants and then learn the syllables. The founder of this method is considered to be a teacher-dzhadidist A.H. Maksudi (1868-1941) who is wellknown among Tatars as the author of the ABC book "Mu'allim thānī" (the Second teacher), published in 1904.

Noting the methodological advantage of his book in comparison with alphabetic method primers, the author wrote: "Instead of having to read by syllables 'Haftiek', it is more accessible and easier to use the ABC book because here we present simple words and it is much easier to read them by syllables. Teachers start to take care of the students not to hurt them in the process of reading the Arabic words by syllables. If children learn to read by syllables, then they can easily switch over to suras"(1904, p. 2). Due to the syllabic method, the process of teaching to read required about two months instead of two years as it was in the case of the alphabetic method.

One of the most educated men of his time A.H. Maksudi who dedicated himself to the service for Tatar people realized that traditional teaching methods were exhausting and schools needed a new approach in teaching children. He developed some guidelines that aimed at implementing the pedagogical skills of teachers, namely the competence, responsibility, individual approach to pupils, justice, etc. His guidelines allow tracing the development of teaching methods since the time of writing Arab textbooks especially for Tatars.

Special recommendations were written with the elements of the opposition revealing how to teach and which teaching techniques used earlier it was better to give up: "It will be reasonable for a teacher not to pronounce the words as the example during reading suras but to give children the opportunity to read themselves; and if a student made a mistake then give him an opportunity to correct this mistake .... Otherwise, waiting till the teacher reads each word, the children will be able only to repeat after him reminding parrots. The teacher should not scold the children for the inability to read the Koran. On the contrary, they should blame themselves that they were not patient enough to wait till students read the words"(1904, p. 3).

\section{Research Methodology}

Despite the big breakthrough in learning to read, the syllabic method had its drawbacks. It did not take into account the sounds coincided with letters and boiled down to the mechanical rote of syllables without showing the process of their formation - for example, how the sounds ' $b$ ' and 'a' form the syllable 'ba'.

Great service of the late XIX century teachers was writing the textbooks in native language of students that radically changed the situation in the teaching of language. The first published manual written in students' native language was the book «Kitab at-tasrif» (Book on morphology) of Rizaetdina Fakhretdinov (1859-1936), a well-known Tatar educator, scholar, theologian, religious and community leader (1887). It was a small book of 75 pages, printed in Kazan on cheap paper with a thin cover.

The basis of teaching aids of local authors were undoubtedly the medieval traditional Arab books. Due to it, most of the works on grammar of Arabic were the translations of the works of Arab authors of the past. At the first glance, the 
translation of Arabic grammar do not seem a difficult process because Arabic grammar was taught in Tatar schools for centuries, and, therefore, had to be studied and mastered by Tatars sufficiently. In reality, the translation of Arab sources required extensive research courage and significant labor from the authors as Tatar grammatical science, being underdeveloped, could not fully explain all the specialty of the foreign language. Moreover, Arabic grammar has got some categories that did not exist in Tatar language, for example, 'masdar', the category of gender, etc.

In the process of teaching when translated books were used, Tatar students realized that the books were not well suited for high-grade teaching because learning of Arabic was not much simplified and communication skills were not developed. Students could not speak the language of the Koran though they used Arabic textbooks and continued to experience serious difficulties in speaking. It should be noted that citing translation examples which confirmed the rules of grammar, the Tatars focused on a simple enumeration of the various grammatical categories without any use of them in speech. So training was focusing on the ability to understand the intricacies of Arabic grammar instead of conversational skills.

In the history of Arabic learning by Tatars, recognized the need for establishment of their traditions of teaching the Arabic language and began to adapt the medieval system of training to the needs of Tatar-speaking audience. They presented Arabic grammar in a very simple way, departing from the canons of Arabic linguistic tradition removing certain grammatical forms and giving some grammatical concepts with their own definitions.

Designed by local authors, new manuals have combined basic components of the classes - introduction of new material, its explanation and rote memorization. The process of memorization was presented in the form of questions and different kinds of exercises. Since the scientific teaching methods had not been developed that time, the use of assignments was a good way for those teachers who did not have sufficient methodological baggage. The training material was based on didactic principles, age and intellectual characteristics of students. Colorful presentation of grammar using examples of Arabic poetry, as well as the Koran and the Hadiths as a peculiarity of traditional Arabic textbooks prevailed over the examples of everyday vocabulary well-known to students. For example: "Haven't you been to Kazan? - We'll go tomorrow. - And what are you going to buy there? - We'll buy ichigi (Tatar highboots) (note 3)"(Bubi, 1899, p. 54).

The highlight in learning the Arabic language was the publishing the first illustrated manual "Mabada' al-qirā'a" (Basic of Reading) made by S. Bikbulatov in 1913.

Many teaching aids of Arabic contained guidelines that - in various degrees - showed the methods of teaching the Arabic language. They allow us to trace the path of their development since the appearance of Arabic textbooks for Tatars. The guidelines show us how attentive the authors were for students. They tried to make learning more effective and interesting. Besides, some researches were done for new solutions in teaching Arabic. In the guidelines, the information about the assessment of written assignments of students can also be found. quantitative assessment

Thus, while checking notebooks, the teachers put the following marks "intikad rakymlary" ("quantitative assessment "):

"1" - Pak Hata, pak fan (quite wrongly, very depressing);

"2 "- Khata, fang (wrongly, frustrating);

"3" - Mutawassit or Maqbool (average, acceptable);

"4" - Hasan, sawab (good, right);

"5"- Ahsan, aswab (very good, quite right).

To assess oral responses, the teacher used praise, encouragement or censure. "Those students who answered correctly are praised and approved by the teacher but those ones who made mistakes are advised to be more attentive and diligent" (Maksudi, 1912, p. 151).

\section{Concluding Remarks and Discussion}

Tatar educators, while teaching Arabic, have got much experience: within 30 years since the publication of the first book on Arabic morphology in Tatar. They published about 50 textbooks. In search of their own tradition of teaching Arabic language, in an attempt to explain the grammatical categories of a foreign language by the means of the native grammatical phenomena and for better understanding, they always adhered to the Arab linguistic tradition.

The experience that Tatars got before the revolution in the field of presentation of Arabic grammar and the terms based on the Arab tradition especially for Tatar-speaking audience, has not lost relevance in the present time. Some of the books of the past can be used nowadays. The Arab tradition features have been adapted for Tatar-speaking audience and they are presented in an accessible form, even for the modern student.

After 1917, and because of the events of October Revolution, Arabic learning stopped for a long time. And only at 
the end of XX century, it began again to be taught in schools. For today, two methods of teaching Arabic exist. The first method is based on the study of language textbooks, created in Soviet times, which were written on the basis of European linguistic terminology. They are the textbooks of B.Z. Khalidov (1981), A.A. Kovalev and G.S. Sharbatov (1999), V.E. Chagal (1993), and others.

The second method is usually used in religious institutions; it is presented by methodology based on the Arabic tradition as it was in the past. In secondary schools, the first methodology is widespread. Such a long break in learning Arabic language, undoubtedly, played its role. Starting to teach Arabic, school teachers faced great difficulties, expressed primarily by the absence of available literature for students. At that time, there were no textbooks written in native language of students and suited the age peculiarities, so the teachers used the books brought by Arabs from the eastern countries. These books, in spite of the colorful illustrations and much information, were not designed for Russian and Tatar-speaking students.

Obviously, the history of learning the Arabic language in school is repeating itself and the problem of modern teachers is to develop their own methodology for Arabic teaching that once was done by Tatar teachers. Perhaps the way that has already been passed the Arab pedagogy will be very useful to connect two points and develop a common methodology, preferably taking all the pros and removing all the disadvantages of these techniques. The first one considers the Arabic language as an object of learning and the second one considers Tatar-speaking environment as a recipient of training.

\section{Referencres}

Al-Zamakhshari (1885). Al- Anmūdhaj. Kazan. Al-Jurjani, Abd al-Qahir. Al-'Awāmil al-mi'a.

Baroudi, G. (189-). Husul al-arab fi nahw lisan al- ‘arab.

Bikbulatov, S. (1913). Basic Reading. Kazan: Magarif.

Bobrovnikov, N. (1913). Russian and Native Schools, Mektebs and Madrassas in Middle Asia. Journal of Public Education Ministry. July. P. 49-84

Bubi, G. (1899). Arab Speaking. Kazan.

Validov, G. (1923). Essay of Tatar education and Literature (till the Revolution of 1917).

Galikaev, Kh. (1899). Mukhtasar al-Kafiya. St. Petersburg.

Introduction to "Bedan" with the comment of Abdullah and Mu'izzi (1883).

Gotwald, I.F. (1855). Arab Manuscripts' of Imperial Kazan University Description. Kazan.

Donish, A. (1960). Travel from Bukhara to St. Petersburg. Tajikistan.

Ibn al-Hajib. (1891). Al-Kāfiya. Istambul.

Ibragimov, F.I. (1969). Tatar Grammar Methodology Development and Primers. Kazan.

Katanov, N.F. (1897). Eastern Bibliography. The Doer. Kazan: Imperial University, 1 (62); 2 (113-120); 12 (696).

Katanov, N.F. (1898). Eastern Bibliography. The Doer. Kazan: Imperial University, 4 (204-206); 8-9 (430); 12 (696).

Katanov, N.F. (1901). Eastern Bibliography. The Doer. Kazan: Imperial University, 8-9 (340).

Koblov, Y. Religious Schools of Kazan Tatars. Kazan: Central Printery.

Kovalev, A.A. \& Sharbatov, G.Sh. (1999). Arabic. Moscow: Eastern Literature.

Maksudi, A. (1904). The second Teacher or Arab ABC book. Kazan.

Maksudi, A. (1912). Oral Classes. Kazan:Kharitonov Matbagasy.

Malov, E. (1894). Muhammed Primer (missioner essay). Kazan: Imperial University.

Program of a six-year primary school (1916). Orenburg.

Ramiev, Kh. (1911).Methdology of Language and Literature Teaching. Шypa. 2.

Safiullina, R.R. (2003). Arab Book in religious culture of Tatars. Kazan: Alma-Lit.

Salakhov, A.M. (2010). Tatar Theory of Grammar Development (basing Arab and Tatar Grammar), (the end of XIX - beginning of XX c.). Institute of Language, Literature and Art n/a G.Ibragimov. Academy of Science of RT, Kazan.

Fakhretdinov, R. (1887). Morphology. Kazan.

Khalidov, B.Z. (1981). Arabic. Tashkent.

Shagal, V.E. (1993). Arabic. Moscow.

\section{Notes}

1. Halfa - a student of Madrasa, an assistant of a teacher.

2. Abjad, Hawwaz, Hutti, Kalamun, Saafas, Qarashat, Sakhathun, Dhathaghun

3. Ichigi - eastern highboots made of soft leather 